\title{
Examining Factors Predicting Students' Digital Competence
}

\author{
Ove Edvard Hatlevik, Gréta Björk Guđmundsdóttir, \\ and Massimo Loi \\ Norwegian Centre for ICT in Education, Oslo, Norway
}

\section{ove.e.hatlevik@iktsenteret.no; greta.gudmundsdottir@iktsenteret.no; massimo.loi@iktsenteret.no}

\begin{abstract}
The purpose of this study was to examine factors predicting lower secondary school students' digital competence and to explore differences between students when it comes to digital competence. Results from a digital competence test and survey in lower secondary school will be presented. It is important to learn more about and investigate what characterizes students' digital competence. A sample of 852 ninth-grade Norwegian students from 38 schools participated in the study. The students answered a 26 item multiple-choice digital competence test and a self-report questionnaire about family background, motivation, and previous grades. Structural equation modeling was used to test a model of the hypothesised relationship between family background, mastery orientation, previous achievements, and digital competence. The results indicate variation in digital competence among the ninth-graders. Further, analyses showed that students' conditions at home, i.e., language integration and cultural capital, together with mastery orientation and academic achievements predict students digital competence. This study indicates that that there is evidence of digital diversity between lower secondary students. It does not seem like the development of digital competence among the students happens automatically. Students' family background and school performance are the most important factors. Therefore, as this study shows, it is necessary to further investigate how schools can identify students' level of competence and to develop plans and actions for how schools can help to try to equalize differences.
\end{abstract}

Keywords: digital competence, structural equation modelling, family background, mastery orientation, average grades, lower secondary school.

\section{Introduction}

For many of us, daily life involves extensive use of information and communication technology

(ICT), including, for example, searching

Material published as part of this publication, either on-line or in print, is copyrighted by the Informing Science Institute. Permission to make digital or paper copy of part or all of these works for personal or classroom use is granted without fee provided that the copies are not made or distributed for profit or commercial advantage AND that copies 1) bear this notice in full and 2) give the full citation on the first page. It is permissible to abstract these works so long as credit is given. To copy in all other cases or to republish or to post on a server or to redistribute to lists requires specific permission and payment of a fee. Contact Publisher@InformingScience.org to request redistribution permission. for, processing, communicating, or producing information at work or for private purposes. The rapid development of ICT for private, public, and business purposes has taken place globally through a variety of technologies, such as computers, tablets, and smartphones.

When examining the use of ICT in the educational systems of the European Union, the European Commission 
(2013) found that countries are choosing different priorities and strategies regarding whether and/or how to implement and use ICT at school. This paper addresses some experiences from Norway, where digital skills and competence have been explicitly described (since 2006) through both general statements and concrete competence aims as part of the subjects in the curriculum (Norwegian Directorate for Education and Training, 2012). We have identified several competence objectives at the end of lower secondary school concerning the use of ICT.

The aim of this paper is to examine the relationship between digital competence, mastery orientation, academic achievements, and family background.

\section{Perspectives}

\section{Digital Competence}

There are several research articles and papers that address what students do and how they learn to use technology for learning and developing (Aviram \& Eshet-Alkalay, 2006; Claro et al., 2012; Eshet, 2012; Gui \& Argentin, 2011; Katz \& MacKlin, 2007). Digital competence (Calvani, Fini, Ranieri, \& Picci, 2012; Ferrari, 2013; Hatlevik \& Christophersen, 2013) is important in Norway because (a) it underpins a flexible and broad understanding of what students are able to do with technology, (b) the concept is operationalized in a recent European framework of digital competence (Ferrari, 2013), and (c) it is in alignment with competence aims in the Norwegian curriculum (Norwegian Directorate for Education and Training, 2012).

Initially, the concept of a digital divide referred to differences in access to computers or the Internet (Pedró, 2007; van Deursen \& van Dijk, 2011; Warschauer, 2002). However, as the differences in access have decreased in Norwegian schools, it seems that other factors are also important, i.e., the students' use at home, years of experience with computers, their academic ambitions, and the family background (Fraillon, Ainley, Schultz, Friedman \& Gebhardt, 2014). Changes in society, school and curriculum demand new digital competence for the students and the teachers. One cause of inequality in digital competence could be that this digital inequality follows existing societal inequalities (Boyd, 2014; van Deursen \& van Dijk, 2011).

This paper defines digital competence as the skills, knowledge, and attitudes that make learners able to use digital media for participation, work, and problem solving, independently and in collaboration with others in a critical, responsible, and creative manner. This is a broad definition compared to the concepts of digital skills or Internet skills. The concept of digital competence includes domains such as student Internet safety awareness, digital communication, retrieving digital information, creating digital content, and problem solving. Moreover, this is an understanding of digital competence in line with the digital competence framework initiated by the European Commission (Ferrari, 2012, 2013) and the 21st Century skills initiative (Binkley et al., 2012).

Assessment of digital competence provides schools, teachers, and students with information about what is recognized as important aspects of digital competence, provides insight into what students master, and can be a tool for the planning of further teaching and education (Calvani et al., 2012).

The Norwegian Directorate for Education and Training (2012) has distinguished between four domains of digital skills and competences: (a) to acquire and process digital information, (b) to produce digital information, (c) digital responsibility, and (d) digital communication. These four domains have been used as guidelines when changing the curriculum and competence aims during 2012 and 2013. Overall, these domains are in line with other frameworks of digital competence (Ferrari, 2013), 21st Century Skills (Binkley et al., 2012) and the International Computer and Literacy study (Fraillon, Schulz, \& Ainly, 2013). 
The Norwegian curriculum contains competence aims as part of subject definitions at the end of $2^{\text {nd }}, 4^{\text {th }}, 7^{\text {th }}$ and $10^{\text {th }}$ grade in primary and lower secondary school. A review of the competence aims at grade level 10 show that at least 40 aims explicitly mention technology. We have identified 20 competence aims in mathematics at grade level 10, at the end of lower secondary school. None of these aims are exclusively digital, but seven out of 20 competence aims have a digital aspect or theme. For example using a spreadsheet for calculations or reading a coordinate system on paper and online.

\section{Mastery Orientation}

Research based on the goal orientation framework attempts to understand and explain the students' mindset when the students participate in learning- or performance-related activities. Mastery orientation is an important perspective within goal orientation (Elliot \& McGregor, 2001; Martin, McGill, \& Sudweeks, 2013; Schunk, Pintrich, \& Meece, 2008). It is important for students who strive for mastery orientation to get insight and understanding and to improve their perceived competence. Mastery oriented students measure their success in terms of selfimprovement. Young students tend to be more mastery-oriented than their older counterparts (Schunk et al., 2008). There are various research findings on the relationship between mastery orientation and achievement (Harackiewicz, Pintrich, Barron, Elliot, \& Trash, 2002; Midgley, Kaplan, \& Middleton, 2001; Urdan, 2004a, 2004b). Younger students' mastery goal orientations are positively related to achievement, motivation and self-regulation (Schunk et al., 2008). Studies have found a positive correlation between digital competence and mastery orientation (Hatlevik \& Christophersen, 2013; Hatlevik, Gudmundsdottir, \& Loi, 2015).

\section{Family Background and Digital Competence}

There are several studies that indicate that family background could explain differences between students when it comes to being able to use technology in learning at school (Calvani et al., 2012; Claro et al., 2012; Erstad, 2010; Fraillon et al., 2014; Krumsvik, Ludvigsen, \& Urke, 2011; Organisation of Economic Co-operation and Development [OECD], 2011). Different kinds of indicators have been used to identify students' family backgrounds: for example, parental background (e.g., education, occupation, salary); immigrant background (e.g., language at home), and cultural goods, such as the number of books at home (Centre for Educational Research and Innovation, 2010; European Commission, 2013; Hargittai, 2010; Hatlevik \& Christophersen, 2013; Ministerial Council for Education, Early Childhood Development and Youth Affairs, 2010).

The PISA (Programme for International Student Assessment) 2009 (OECD, 2011) and 2012 Kjærnsli \& Olsen, 2013) studies used 'number of books at home' as an indicator of family and socio-economic background. The 'number of books at home' based on the theory by Bourdieu serve as a proxy of cultural capital (Bourdieu \& Thompson, 1991). Several studies have found that socio-economic background, i.e., cultural capital, is related with achievements in school (Norwegian Directorate for Education and Training, 2014; NOU, 2010; OECD, 2011). Analysis of the Norwegian results from exams and the national tests reveal that "indicators of a pupil's socio-economic background explains most of the variance" (Norwegian Directorate for Education and Training, 2014, p. 80).

Results from students' digital reading performance in the PISA 2009 showed a positive correlation between cultural capital ('number of books at home') and Norwegian students' digital reading performance $(\mathrm{r}=.09)$ (Frønes \& Narvhus, 2011). When examining digital competence, positive correlations were found between students' cultural capital and their digital competence (Hatlevik \& Christophersen, 2013; Hatlevik et al., 2015). 
Students' language background is defined as part of the students' home environment in the International Computer and Information Literacy Study (ICILS) (Fraillon et al., 2014). Studies show that language integration, measured by language at home, is correlated with students' digital competence (Hatlevik \& Christophersen, 2013; Hatlevik et al., 2015). Analysis of the Norwegian national tests and final examinations, show that students with immigrant backgrounds achieve at the $8^{\text {th }}$ and $10^{\text {th }}$ grade lower scores compared to children with non-immigrant backgrounds (NOU, 2010). One explanation of these differences could be the language spoken at home.

Finally, Norwegian studies (Hatlevik, 2010; Krumsvik, Egelandsdal, Sarastuen, Jones, \& Eikeland, 2013) indicate that students with higher marks/grades overall demonstrate more digital competence. First, this shows how digital competence and academic performance do not oppose one another. Second, this reveals how students with academic success also tend to succeed when measured in transversal competences.

\section{Research Hypotheses and Theoretical Model}

This paper addresses the factors predicting students' digital competence. A model with five factors has been developed (see Figure 1). Five hypotheses describe family background with language integration and cultural capital.

H1: There exists a positive correlation between language integration and cultural capital.

H2: Cultural capital predicts academic achievement.

H3: Cultural capital predicts digital competence.

H4: Language integration predicts mastery orientation.

H5: Language integration predicts digital competence.

Three hypotheses describe previous academic achievements, i.e., average grades, and mastery orientation.

H6: Previous academic achievements predict mastery orientation.

H7: Previous academic achievements predict digital competence.

H8: Mastery orientation predicts digital competence.

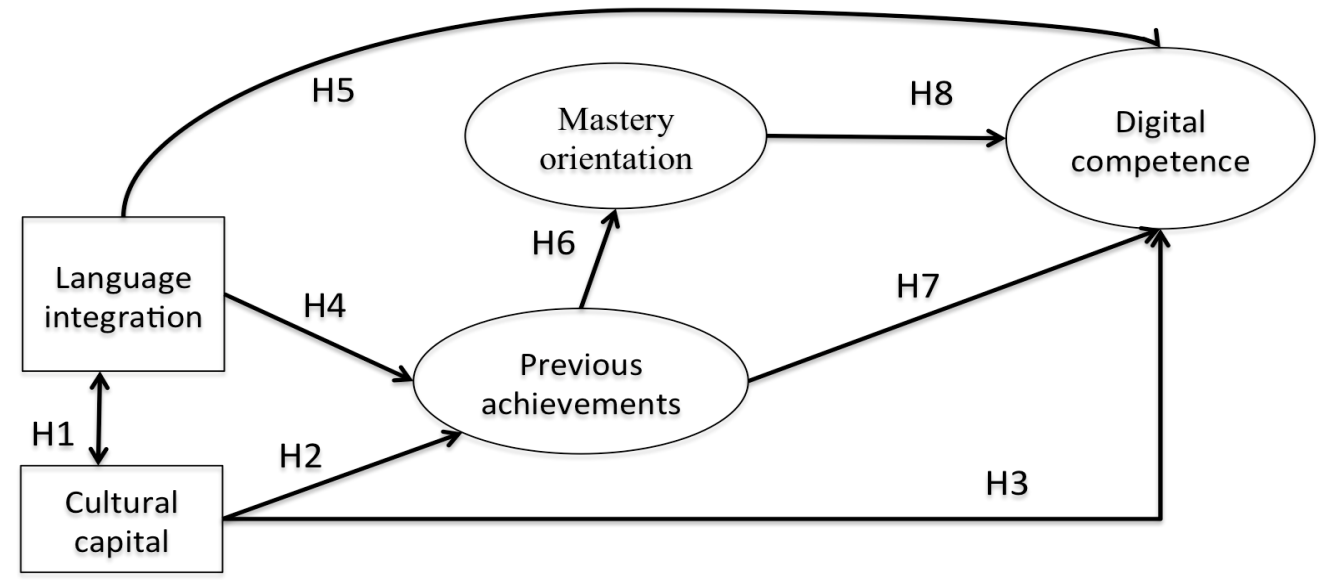

Figure 1: Theoretical model showing the relationship between students family background, their personal characteristics and digital competence (a rectangle represent a manifest variable and an ellipse represent a latent variable) 
Hatlevik, Guðmundsdóttir, \& Loi

\section{Method}

\section{Procedures and Participants}

This is a cross-sectional survey with a two-step selection of students. Initially, 150 schools with $9^{\text {th }}$ grade students were randomly selected in 2013. All 150 schools were contacted by regular mail, e-mail, and by phone. Schools not willing to participate were not replaced. The schools were asked to choose one class to participate in the survey. The schools received e-mail with information on how to administrate the survey and how to provide access to the online survey for the participating students. The final sample consisted of 852 students from 38 participating schools. The response rate at school level was $25.3 \%$.

\section{Measures}

The survey consisted of a questionnaire with self-report questions and a test section with multiple-choice questions. Cronbach's alpha was used as a measure of the internal consistency of the items.

A test with 26 multiple-choice questions was used to measure digital competence. Each multiplechoice question had four alternative response options, with only one correct answer per question. We used automatic scoring of the answers, and the students received 1 point for each correct answer. A Cronbach's alpha $=0.74$ indicated an acceptable level of consistency for the multiplechoice test.

The questions were developed on the basis of the competence aims in the national curriculum at the end of $10^{\text {th }}$ grade. The questions covered various themes: five questions about digital responsibility, three questions about digital communication, eight questions about how to retrieve and handle digital information, and ten questions about how to create and process digital information. The items are presented in Table 2 in a following section.

In addition to the test, the students answered a self-report questionnaire about cultural capital, language integration, and mastery orientation. In order to identify students' culture capital (Bourdieu \& Thompson, 1991) the student was asked about the number of books at home. There are several reasons why the number of books is used as a measure for cultural capital. First, students can give a fairly correct estimate of the number of books at home. Second, it is not a sensitive theme compared with family financial situation or education, and third, the number of books has been used in several other international studies (Frønes \& Narvhus, 2011). In the coding of students' responses 1 corresponded to "no books", 2 to " $1-10$ books", 3 to " $11-50$ books", 4 to " $51-$ 100 books", 5 to "101-250 books", 6 to " $251-500$ books", and 7 to "more than 500 books".

Language integration was measured by one question about what language the students spoke at home. Only Norwegian at home was coded as 0 , whereas a language other than Norwegian or another language in combination with Norwegian was coded as 1 .

In order to assess students' mastery orientation, the students responded to three statements, developed from Elliot and McGregor (2001). They answered on a Likert-type agree-disagree scale, ranging from 'Strongly agree' (4) to 'Strongly disagree' (1). Most of the students agreed with the statements about mastery orientation, and therefore the answers were recoded as 'strongly agree' $=2$ and all other responses $=1$. The Cronbach's alpha $=0.70$ indicated an acceptable level of consistency.

The students were also asked about what marks/grades they achieved the previous autumn semester in the following four subjects: Norwegian, social science, mathematics, and science. The scale of marks/grades are 1 (the lowest mark), 2, 3,4, 5 and 6 (the highest mark). Cronbach's alpha = 0.87 indicated a high level of consistency. 
Additionally, information from a national database (www.gsi.udir.no) was used to identify the number of students per computer in the participating schools. The average number of students per computer was 2.19 (sd 0.71).

\section{Statistical Analysis}

Overall, the items in the study have reasonable levels of skewness and kurtosis. Skewness refers to whether the distribution of an item or factor differs from the normal distribution, whereas kurtosis provides information whether there is a pointed or flat distribution of data. Mastery orientation recoded into two alternatives.

There can be missing data in a survey and this has implications for the analyses of the data. There are different approaches to solve this problem, for example, to remove respondents or to replace missing values. The latter approach requires that there is no systematic missing of data. Little's missing completely at random (MCAR) test (Polit \& Beck, 2004) can be used to check if data is missing at random or not. The results of this analysis (chi-square $=12.9, \mathrm{DF}=16$, and $P=0.68$ showed that the data were missing completely at random and that, consequently, it was possible to replace missing values.

The model is tested using structural equation modelling (SEM) with latent variables (Brown, 2006; Kline, 2010; MacCallum, Jeffrey, \& Kinshuk, 2014). SEM provides the opportunity to simultaneously conduct analysis of the items used to measure the factors and at the same time examine the relationship between multiple dependent and independent variables (Geiser, 2013). SEM can be run with both continuous and categorical variables (Kline, 2010). One benefit of SEM is getting the measurement model tested, i.e., analysing the relationship between the observed items/questions and the latent factors. Another benefit is having the relationship, i.e., as correlations or regression coefficients, between the latent factors tested. In this way the theoretical model in Figure 1 could be tested with an empirical dataset, and it is possible to get an estimation of the model fit of the comparison.

To evaluate the fit of the model with the hypotheses, two fit indices were used, the comparative fit index (CFI) and the Tucker-Lewis fit index (TLI). Both the CFI and the TLI compare the userspecified model with a more restricted model (Brown, 2006). Levels of CFI and TLI close to or above 0.95 are acceptable (Brown, 2006; Hu \& Bentler, 1999; Kline, 2010). Further, the root mean square error of approximation (RMSEA) is calculated in order to estimate the misspecification of the model. A RMSEA level below 0.06 indicates a good fit and good specifications of the model.

Finally, the internal structure of the model has to have high quality. We are therefore looking closely at the correlations, i.e., factor loadings, between each item and the latent variables. The levels of factor loadings have to meet the following criteria: (1) the factor loadings have to be statistically significant on a 5\% level, (2) factor loadings $>0.40$ are desirable, and (3) factor loadings $>0.20$ are acceptable. This is in line with recommended levels of discrimination coefficient from classical test theory (Crocker \& Algina, 2006; McAlpine, 2002).

\section{Data Collection and Protection}

The study followed the guidelines on data collection and privacy protection from the Norwegian Social Science Data Services (www.nsd.uib.no). We sent the Norwegian Social Science Data Services an application for the study, and we started the study when they accepted our application. Participation of students was voluntary, students had the option to withdraw from the study until they submitted the questionnaire, the questions were not considered sensitive by the Norwegian Social Science Data Services, and we did not collect any direct or indirect personally identifiable information. 


\section{Results}

The data were analysed using IBM SPSS, version 21 and Mplus 7.0.

\section{Students Background}

Students answered how many books they have at home: as shown in Table 1, 2.5\% answered no books at home and $10.2 \%$ had between 1 and 10 books, $15.9 \%$ had between 11 and 50 books, $15.4 \%$ had between 51 and 100 books, $22.2 \%$ had between 101 and 250 books, $17.0 \%$ had between 251 and 500 books, and $16.8 \%$ had more than 500 books at home.

\begin{tabular}{|l|l|l|}
\hline \multicolumn{2}{|c|}{ Table 1: The distribution of books at home and language at home } \\
\hline VARIABLES & \multicolumn{1}{|c|}{ VALUES } & FREQUENCY \\
\hline \multirow{4}{*}{ Books at home } & None & $2.5 \%$ \\
\cline { 2 - 3 } & $1-10$ books & $10.2 \%$ \\
\cline { 2 - 3 } & $11-50$ books & $15.9 \%$ \\
\cline { 2 - 3 } & $51-100$ books & $15.4 \%$ \\
\cline { 2 - 3 } & $101-250$ books & $22.2 \%$ \\
\cline { 2 - 3 } & $251-500$ books & $17.0 \%$ \\
\cline { 2 - 3 } & More than 500 books & $16.8 \%$ \\
\hline \multirow{3}{*}{ Language integration } & Norwegian at home & $16.7 \%$ \\
\cline { 2 - 3 } & $\begin{array}{l}\text { Another language; other than Norwegian } \\
\text { or combined with Norwegian }\end{array}$ \\
\hline
\end{tabular}

For student responses to the question about language spoken at home a total of $83.3 \%$ spoke only Norwegian at home, and $16.7 \%$ spoke Norwegian and another language or just a language other than Norwegian at home.

\section{Psychometric Properties: Overall Model Fit}

In this design the students are nested in schools. On one hand it seems appropriate to use multilevel modelling on the data. However, most of the variance in digital competence is found within schools and not between schools. It seems therefore of limited value to use a multilevel model instead of a structural equation model.

A model of with the hypotheses from Figure 1 was converged to an acceptable solution. All parameters and relationships within the model are statistically significant. However, two items measuring digital competence had to be removed due to factor loadings below 0.20 . A new analysis without those two multiple-choice items was run. The analyses of the revised model showed acceptable test fit results. The values of CFI $=0.947$, TLI $=0.943$, and the RMSEA $=0.024$ [LO $90=0.020$ and HI $90=0.027]$.

Table 2 contains information about the item analysis, the consistency for the self-report questions, and the multiple choice questions, as well as, the means, factor loadings, and standard errors of all items. The results of the assessment of the quality of the internal structure of the model reveal that factor loadings of the multiple choice items and the self-report items are significant $(p<0.01)$ and that they are above 0.20 . 


\begin{tabular}{|c|c|c|c|}
\hline & MEAN & LOADING & S.E. \\
\hline \multicolumn{4}{|l|}{ Mastery orientation $(\mathrm{CA}=0.70)$ as latent variable } \\
\hline \multicolumn{4}{|l|}{ How do you agree or disagree to these statements? } \\
\hline I want to learn as much as possible at school. & 3.70 & $0.83 * *$ & 0.03 \\
\hline $\begin{array}{l}\text { It is important for me to have the best possible understanding } \\
\text { of the school subjects. }\end{array}$ & 3.80 & $0.93 * *$ & 0.03 \\
\hline I want to master all the subjects at school. & 3.70 & $0.70^{* *}$ & 0.04 \\
\hline \multicolumn{4}{|l|}{ Previous achievements $(\mathrm{CA}=0.87)$ as latent variable } \\
\hline Grade in Norwegian subject previous semester & 4.13 & $0.69 * *$ & 0.03 \\
\hline Grade in Social science subject previous semester & 4.27 & $0.80 * *$ & 0.02 \\
\hline Grade in Science subject previous semester & 4.19 & $0.85^{* *}$ & 0.02 \\
\hline Grade in Mathematics subject previous semester & 4.00 & $0.81^{* *}$ & 0.03 \\
\hline \multicolumn{4}{|l|}{ Digital competence $(\mathrm{CA}=0.74)$ as latent variable } \\
\hline Which statement about Wikipedia is wrong? & 0.35 & $0.36^{* *}$ & 0.04 \\
\hline $\begin{array}{l}\text { You believe that there should be no homework for students. } \\
\text { How do you influence decision makers? }\end{array}$ & OUT & - & - \\
\hline $\begin{array}{l}\text { You have found a poem that you will use in an assignment. } \\
\text { What can you do? }\end{array}$ & 0.65 & $0.61 * *$ & 0.04 \\
\hline $\begin{array}{l}\text { Which of these statements about the difference between ad- } \\
\text { vertising on the Internet and on TV is most correct? }\end{array}$ & 0.27 & $0.27 * *$ & 0.05 \\
\hline One of these is NOT a browser, which one? & 0.82 & $0.30^{* *}$ & 0.06 \\
\hline $\begin{array}{l}\text { How do you best refer to the sources in the answer of the } \\
\text { assignment? }\end{array}$ & 0.48 & $0.65 * *$ & 0.04 \\
\hline $\begin{array}{l}\text { Can you trust the information you find on "Store norske } \\
\text { leksikon"? }\end{array}$ & 0.58 & $0.42 * *$ & 0.05 \\
\hline $\begin{array}{l}\text { Is it possible for strangers to find out which pages you visited } \\
\text { and what search words you used on the Internet? }\end{array}$ & 0.52 & $0.53 * *$ & 0.04 \\
\hline What does it mean that the email is encrypted? & 0.43 & $0.31^{* *}$ & 0.05 \\
\hline What is a wiki? & 0.43 & $0.22 * *$ & 0.05 \\
\hline What is a "cookie"? & 0.64 & $0.51 * *$ & 0.04 \\
\hline $\begin{array}{l}\text { Which digital tools to choose when communicating with } \\
\text { students in Japan during lessons? }\end{array}$ & 0.49 & $0.34 * *$ & 0.05 \\
\hline
\end{tabular}




\begin{tabular}{|c|c|c|c|}
\hline & MEAN & LOADING & S.E. \\
\hline $\begin{array}{l}\text { Mary will post a presentation online. Can she use any image } \\
\text { from a photo sharing service in her presentation? }\end{array}$ & 0.68 & $0.52 * *$ & 0.04 \\
\hline Why should you refer to sources in a project? & 0.60 & $0.64 * *$ & 0.04 \\
\hline What is the best way to refer to sources in an assignment? & 0.34 & $0.40 * *$ & 0.05 \\
\hline $\begin{array}{l}\text { Who owns the images John posts on his profile on Face- } \\
\text { book? }\end{array}$ & OUT & - & - \\
\hline $\begin{array}{l}\text { Can John delete his profile on Facebook? What is the most } \\
\text { correct? }\end{array}$ & 0.52 & $0.47 * *$ & 0.04 \\
\hline $\begin{array}{l}\text { Marie wants to include a film as a part of her presentation. } \\
\text { How to enter the film so that it becomes part of the presenta- } \\
\text { tion? }\end{array}$ & 0.32 & $0.30 * *$ & 0.05 \\
\hline $\begin{array}{l}\text { When downloading a picture from the Internet, can a virus } \\
\text { attack your digital device? }\end{array}$ & 0.58 & $0.33^{* *}$ & 0.05 \\
\hline $\begin{array}{l}\text { How can you use the computer to replace names of countries } \\
\text { in a text? }\end{array}$ & 0.14 & $0.26^{* *}$ & 0.06 \\
\hline $\begin{array}{l}\text { You should sum the numbers from } 30 \text { cells in column } \mathrm{H} \text {. } \\
\text { Which formula is correct? }\end{array}$ & 0.41 & $0.38^{* *}$ & 0.05 \\
\hline $\begin{array}{l}\text { You should sum the numbers from } 20 \text { cells in row } 7 \text { Which } \\
\text { formula is correct? }\end{array}$ & 0.33 & $0.23 * *$ & 0.05 \\
\hline $\begin{array}{l}\text { You are asked to copy the text into a word processor and } \\
\text { identify how many times the word "Climate" is repeated. }\end{array}$ & 0.61 & $0.53 * *$ & 0.04 \\
\hline $\begin{array}{l}\text { Which number is misspelled in the text? Tip: Use the spell } \\
\text { checker in Word or similar. }\end{array}$ & 0.45 & $0.60 * *$ & 0.04 \\
\hline $\begin{array}{l}\text { A table shows the revenue for a store run by students. What } \\
\text { is the total income for the whole week? }\end{array}$ & 0.46 & $0.58^{* *}$ & 0.04 \\
\hline $\begin{array}{l}\text { A table shows the revenue for a store run by students. What } \\
\text { is the total income for Friday, Saturday and Sunday? }\end{array}$ & 0.30 & $0.24 * *$ & 0.05 \\
\hline \multicolumn{4}{|l|}{ Single items (manifest variables) } \\
\hline Language integration & 3.79 & - & 0.11 \\
\hline Cultural capital & 3.13 & - & 0.07 \\
\hline
\end{tabular}


Figure 2 contains the regression paths between the factors in the model and the explained variance in the dependent variables. All the regression coefficients are significant. The data explains $14 \%$ of the variation in mastery orientation, $12 \%$ of the variation in previous achievements and $30 \%$ of the variation in digital competence.

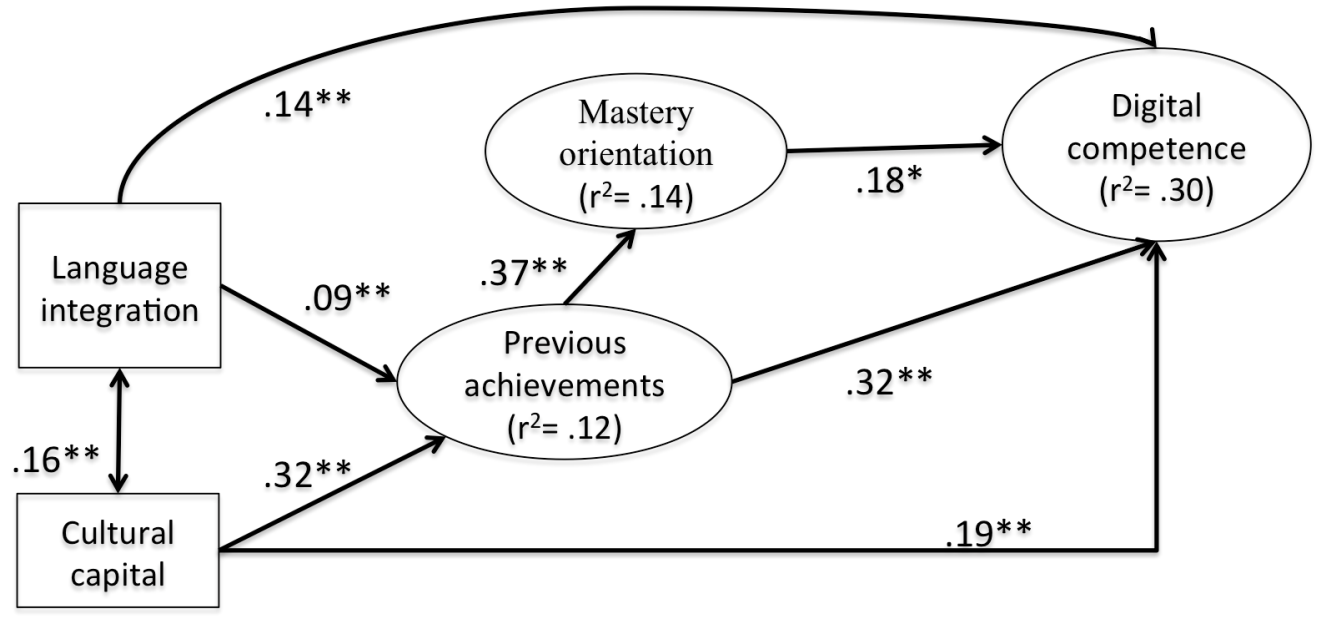

Figure 2: Results from the testing of the theoretical model with the seven hypotheses about relationship between students' language integration, cultural capital, previous achievements, mastery orientation and digital competence (a rectangle represent a manifest variable and an ellipse represent a latent variable)

\section{Discussion}

This paper addresses a model describing the relationship between students' family background, previous achievements at school, mastery orientation, and digital competence. The model was developed with eight hypotheses emphasising cultural capital, language at home, strategic use of information, previous academic achievements, and predicted competence. The analysis of the model shows that all the eight hypotheses are supported.

The findings from the SEM approach reveal that students' cultural capital and language integration at home is positively related. Further, the model shows that students' cultural capital and language integration at home have a positive prediction of digital competence. The findings are in line with other studies (Claro et al., 2012; Ministerial Council for Education, Early Childhood Development and Youth Affairs, 2010; Tondeur, Sinnaee, van Houtte, \& van Braak, 2011) reporting that indicators of students' family background play a role when explaining variations in digital competence. Boyd (2014) underpins that social differences in society do not disappear when students use technology. Cultural capital and language integration at home can be understood as proxies of students' family background (Erstad, 2010; Selwyn, 2008). This means that school leaders and teachers have to be aware of students' family background when planning and conducting teaching.

The analysis shows that students' mastery orientation has a positive prediction of digital competence. It is important that students develop a motivation for learning at school. However, we still need more information about how teachers can help students to develop adaptive strategies for information use.

Finally, digital competence is predicted by students' previous academic achievements. One explanation can be that succeeding at school is more likely to benefit from the introduction of ICT 
at school. It appears that differences in academic achievement contribute to explaining differences in digital competence between the students. It seems difficult to obtain digital equity between the students because digital competence and digital equity follow the pattern of results from other academic studies (Boyd, 2014; Fraillon et al., 2014; Pedró, 2007; Selwyn, 2008). Further, these analyses indicate that competence and academic performance do not oppose each other. Instead it is apparent that previous school performance can predict students' ability to perform on a test measuring digital competence.

Nevertheless, when it comes to explaining digital competence, the results from multilevel analysis indicate that students' family background and students' characteristics, measured by strategic information use and previous achievements, are the most import factors for understanding digital equity and student achievement in digital competence.

\section{Conclusion}

\section{Limitations}

The study has some limitations and they have to be mentioned. First, the response rate is $25.3 \%$ at school level. Second, when using an online survey, the students and schools having a positive attitude towards technology could be overrepresented. The average number of students per computer was 2.19 in the participating schools and 2.30 on the national level. It does not look like the sample differs greatly from the national average. Third, a self-selection bias could occur because it was not mandatory to participate in the study. However we find variation in digital competence between the students. It seems that a rather heterogeneous sample of students has participated, and that the schools are rather similar. Nevertheless, the results from the study give insight into factors predicting digital competence.

\section{Concluding Remarks}

To conclude, some of the students in the study could answer most of the questions correctly, whereas other students did not know the correct answer to many of the questions. Such findings indicate diversity in digital competence among the students. The difference in achievement between students is supported by many national tests and international studies of, for example, reading, mathematics, science, and information literacy (Fraillon et al, 2014; The Norwegian Directorate for Education and Training, 2014; OECD, 2011; Wiborg, Arnesen, Grøgaard, Støren, \& Opheim, 2011).

According to Boyd, it "is dangerous to assume that youth are automatically informed. It is also naive to assume that so-called digital immigrants have nothing to offer.... Becoming literate in a networked age requires hard work, regardless of age" (Boyd, 2014, p. 177). Digital skills and competence requires hard work and persistence as does developing other key competences such as reading, writing, or doing calculations.

How schools and teachers deal with diversity in students' digital competence is a two part question. First, are the schools and teachers capable of identifying the diversity in students' digital competence? Second, if the schools or teachers are able to identify digital diversity, are they able to take action in order to increase their students' digital competence? Clearly, identifying digital diversity requires that the schools and the teachers prioritise digital competence during lessons and school activities. A recent international study (Fraillon et al, 2014) shows that, among Norwegian $9^{\text {th }}$ grade students, there are $75 \%$ using ICT at home daily whereas $8 \%$ are using ICT at school daily. This could indicate that using ICT is not given high priority when learning subjects in $9^{\text {th }}$ grade. One suggestion is that schools could give higher priority to teaching students how to use ICT in order to fulfil the competence aims in the curriculum. It could perhaps reduce dispari- 
ties, if the teachers and school leaders emphasize training students in digital competence at school. Additionally, it seems worthwhile to examine what characterizes the people responsible for ICT in schools and if they experience pedagogical and technological personal empowerment (Avidov-Ungar \& Shamir-Inbal, 2013).

Family background, measured by cultural capital and language integration, is related to digital competence. Family background can explain the lack of digital equity. Researchers (Boyd, 2014; Selwyn, 2008) conclude that social differences outside school are having an impact on online activities, self-representation, and digital equity.

Finally, students' previous achievements at school and their mastery orientation seem important. Motivation for learning at school is related with both digital competence and previous achievements. Additionally, students' benefit from their previous results on tests, and previous achievements are important for digital competence. It turns out that some students succeed consistently in subjects and across subjects, while other students have greater difficulty succeeding on tests.

Future studies are required in order to examine more closely how the relationship between students average grades, student strategic use of information, and student digital competence changes through secondary school.

\section{References}

Avidov-Ungar, O., \& Shamir-Inbal, T. (2013). Empowerment patterns of leaders in ICT and school strengths following the implementation of national ICT reform. Journal of Information Technology Education: Research, 12, 141-158. Retrieved November 24, 2014, from http://www.jite.org/documents/Vol12/JITEv12ResearchP141-158Avidov1228.pdf

Aviram, A., \& Eshet-Alkalai, Y. (2006). Towards a theory of digital literacy: Three scenarios for the next steps. European Journal of Open, Distance and E-Learning. Retrieved May 15, 2014, from http://www.eurodl.org//materials//contrib//2006//Aharon_Aviram.htm

Binkley, M., Erstad, E., Herman, J., Raizen, S., Ripley, M., Miller-Ricci, M., \& Rumble, M. (2012). Defining 21st century skills. In P. Griffin, B. McGaw, \& E. Care (Eds.), Assessment and teaching of 21 st century skills (pp. 17-66). Dordrecht, the Netherlands: Springer. doi:10.1007/978-94-007-2324-5

Bourdieu, P., \& Thompson, J. B. (1991). Language and symbolic power. Cambridge: Polity Press.

Boyd, D. (2014). It's complicated. London: Yale University Press.

Brown, T. A. (2006). Confirmatory factor analysis for applied research. London: The Guilford Press.

Calvani, A., Fini, A., Ranieri, M., \& Picci, P. (2012). Are young generations in secondary school digitally competent? A study on Italian teenagers. Computers and Education, 58, 797-807.

Centre for Educational Research and Innovation \& Organisation of Economic Co-operation and Development. (2010). Are the new millennium learners making the grade? Technology use and educational performance in PISA. Paris: CERI/OECD. Retrieved November, 24, 2014, from http://www.oecdilibrary.org/education/inspired-by-technology-driven-by-pedagogy 9789264094437-en

Claro, M., Preiss, D. D., San Martín, E., Jara, I., Hinostroza, J. E., Valenzuela, S., \& Nussbaum M. (2012). Assessment of 21 st century ICT skills in Chile: Test design and results from high school level students. Computers \& Education, 59, 1042-1053.

Crocker, L., \& Algina, J. (2006). Introduction to classical and modern test theory. Florence, KY: Cengage Learning.

Elliot, A. J., \& McGregor, H. A. (2001). A 2 X 2 achievement goal framework. Journal of Personality and Social Psychology, 80, 501-519.

Erstad, O. (2010). Educating the digital generation: Exploring media literacy for the 21st century. Nordic Journal of Digital Literacy, 5(1), 56-71. 
Eshet, Y. (2012). Thinking in the digital area: A revised model for digital literacy. Issues in Informing Science and Information Technology, 9, 267-276. Retrieved November 24, 2014, from http://iisit.org/Vol9/IISITv9p267-276Eshet021.pdf

European Commission. (2013). Survey of schools: ICT in education. Luxembourg: The European Union.

Ferrari, A. (2012). Digital competence in practice: An analysis of frameworks (Report EUR 25351 EN). Luxembourg: The European Union.

Ferrari, A. (2013). DIGCOMP: A framework for developing and understanding digital competence in Europe. Luxembourg: The European Union. Retrieved February 6, 2015, from http://ipts.jrc.ec.europa.eu/publications/pub.cfm?id=6359

Fraillon, J., Ainley, J., Schulz, W., Friedman, T., \& Gebhardt, E. (2014). Preparing for life in a digital age: The IEA international computer and information literacy study international report. Melbourne: Springer.

Fraillon, J., Schulz.W., \& Ainley, J. (2013). International computer and information literacy study: Assessment framework. Amsterdam: IEA

Frønes T. S., \& Narvhus E. K. (2011). Elever på nett - Digital lesing i PISA 2009 [Students on the Internet: Digital reading in PISA 2009]. Oslo: Universitetsforlaget.

Geiser, C. (2013). Data analysis with Mplus. London: The Guildford Press

Gui, M., \& Argentin, G. (2011). Digital skills of internet natives: Different forms of internet literacy in a random sample of northern Italian high school students. New Media \& Society, 13(6), 963-980.

Harackiewicz, J. M., Pintrich, P. R., Barron, K. E., Elliot, A. J., \& Trash, T. M. (2002). Revision of achievement goal theory: Necessary and illuminating. Journal of Educational Psychology, 94, 638645.

Hargittai, E. (2010). Digital na(t)ives? Variation in Internet skills and uses among members of the 'Net Generation.' Sociological Inquiry, 80(1), 92-113.

Hatlevik, O. E. (2010). Examining 'Digital Divide' in upper secondary school: A multilevel analysis of factors with an influence on digital competence. The International Journal of Technology, Knowledge and Society, 6(3), 151-164.

Hatlevik, O. E., \& Christophersen, K. S. (2013). Digital competence in the beginning of upper secondary school: Digital inclusion. Computers \& Education, 63, 240-247.

Hatlevik, O. E., Gudmundsdottir, G. B., \& Loi, M. (2015). Digital diversity among upper secondary students: A multilevel analysis of the relationship between cultural capital, self-efficacy, strategic use of information and digital competence. Computers and Education, 81, 345-353.

Hu, L. T., \& Bentler, P. M. (1999). Cutoff criteria for fit indexes in covariance structure analysis: Conventional criteria versus new alternative. Structural Equation Modeling, 6(1), 1-55.

Katz I. R., \& Macklin A. S. (2007). Information and communication technology (ICT) literacy: Integration and assessment in higher education. Systemics, Cybernetics and Informatics, 5(4), 50-55.

Kjærnsli, M., \& Olsen, R. V. (2013). Fortsatt en vei å gå. Norske elever i matematikk, naturfag og lesning $i$ PISA 2012 [Still a way to go: Norwegian students in math, science and reading in PISA 2012]. Oslo: Universitetsforlaget.

Kline, R. B. (2010). Principles and practice of structural equation modelling ( $3^{\text {rd }}$ ed.). New York: The Guilford Press.

Krumsvik, R. J., Egelandsdal, K., Sarastuen, N. K., Jones, L. Ø., \& Eikeland, O. J. (2013). Sammenhengen mellom IKT-bruk og lceringsutbytte i videregaiende opplcering. [The relationship between the use of ICT and learning outcome in upper secondary school]. Bergen: University of Bergen. 
Krumsvik, R. J., Ludvigsen, K., \& Urke, H. B. (2011). Klasseleiing og IKT $i$ vidaregåande opplaring. DLC-rapport $n r .1 / 2011$. [Class management and ICT in upper secondary education. DLC report nr.1/2011.] Bergen, Norway: University of Bergen.

MacCallum, K., Jeffrey, L., \& Kinshuk. (2014). Factors impacting teachers' adoption of mobile learning. Journal of Information Technology Education: Research, 13, 141-162. Retrieved November 24, 2014, from http://www.jite.org/documents/Vol13/JITEv13ResearchP141-162MacCallum0455.pdf

Martin, R., McGill, T., \& Sudweeks, F. (2013). Learning anywhere, anytime: Student motivators for Mlearning. Journal of Information Technology Education: Research, 12, 51-67. Retrieved November 24, 2014, from http://www.jite.org/documents/Vol12/JITEv12ResearchP051-067MartinFT51.pdf

McAlpine, H. (2002). A summary of methods of item analysis. Bluepaper Number 2. Glasgow: University of Glasgow

Midgley, C., Kaplan, A., \& Middleton, M. (2001). Performance-approach goals: Good for what, for whom, under what circumstances and at what cost? Journal of Educational Psychology, 93, 77-86.

Ministerial Council for Education, Early Childhood Development and Youth Affairs. (2010). National Assessment Program. ICT literacy years 6 and 10 report 2008. Carlton South, VIC, Australia: Curriculum Corporation. Retrieved February 7, 2014, from http://www.nap.edu.au/verve/_resources/2008_nap_ictl_public_report.pdf

Norwegian Directorate for Education and Training. (2012). Framework for basic skills. Retrieved July 15, 2014, from http://www.udir.no/Stottemeny/English/Curriculum-in-English/ english/Framework-forBasic-Skills/

Norwegian Directorate for Education and Training. (2014). The education mirror. Retrieved January 6, 2015, from http://utdanningsspeilet.udir.no/en/

NOU (2010). Mangfold og mestring. Flerspråklige barn, unge og voksne i opplceringssystemet [Diversity and mastery: Multilingual children, youth and adults in the education system]. NOU 2010:7. Oslo: Norway.

Organisation of Economic Co-operation and Development (OECD). (2011). PISA 2009. results: Students on line digital technologies and performance (Vol VI). Paris, France: OECD.

Pedró, F. (2007). The new millennium learners: Challenging our views on digital technologies and learning. Nordic Journal of Digital Literacy, 2(4), 43-60.

Polit, D. F., \& Beck, C. T. (2004). Nursing research. principles and methods ( $7^{\text {th }}$ ed.). Philadelphia: Lippincott Williams \& Wilkins.

Schunk D. H., Pintrich P. R., \& Meece J. L. (2008). Motivation in education: Theory, research, and applications. Upper Saddle River, NJ: Pearson/Merrill Prentice Hall.

Selwyn, N. (2008). The digital native - Myth and reality. Aslib Proceedings, 61(4), 364-379.

Tondeur, J., Sinnaee, I., van Houtte, M., \& van Braak, J. (2011). ICT as cultural capital: The relationship between socioeconomic status and the computer-use profile of young people. New Media \& Society, $13,1-18$.

Urdan, T. (2004a). Can achievement goal theory guide school reform. In P. R. Pintrich, \& M. L. Maehr (Eds.). Advances in motivation and achievement: Vol.13. Motivating students, improving schools: The legacy of Carol Midgley (pp. 361-392). London: Elsevier

Urdan, T. (2004b). Predictors of academic self-handicapping and achievement: Examining achievement goals, classroom goal structures, and culture. Journal of Educational Psychology, 96, 251-264.

van Deursen, A. J. A. M., \& van Dijk, J. A. G. M. (2011). Internet skills and the digital divide. New Media \& Society, 13(6), 893-911.

Warschauer, M. (2002). Reconceptualizing the digital divide. First Monday, 7(7). Retrieved July 15, 2014, from http://firstmonday.org/article/view/967/888 
Wiborg, Ø., Arnesen, C. Å., Grøgaard, J., Støren, L. A., \& Opheim, V. (2011). Elevers prestasjonsutvikling - hvor mye betyr skolen og familien? Andre delrapport frå prosjektet "Ressurser og resultater" [The development of pupils performance - how much does the school and the family matter? Second report from the project "Resources and Results"]. Rapport 35. Oslo: NIFU

\section{Biographies}

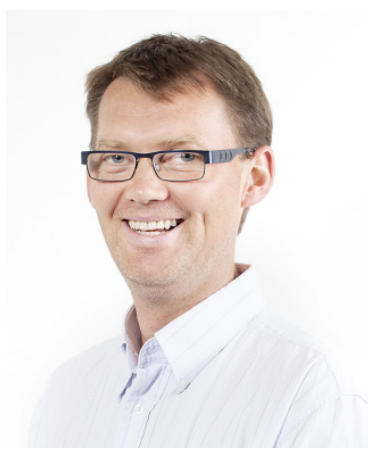

Ove Edvard Hatlevik is a researcher at the Norwegian Centre for ICT in Education. He holds a Ph.D in educational research from the University of Oslo. His research interests are human factors in aviation, learning strategies and motivation in learning with technology, test development and how schools develop leadership when implementing information and communication technology (ICT). At present he is involved in projects to identify and measure digital competence based on national and international frameworks for digital competence/literacy. He is a co-editor of the Nordic Journal of Digital Literacy.

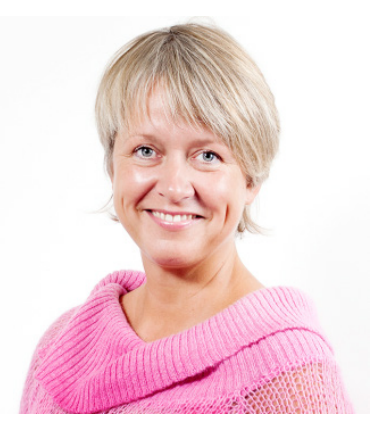

Gréta Björk Guðmundsdóttir is a researcher at the Norwegian Centre for ICT in Education. She holds a Ph.D in Comparative and International Education from the University of Oslo. She has conducted research in several countries in Africa on ICT integration in teacher education and the appearance of digital divide faced by schoolchildren and teachers in Southern Africa. At present she is a part of the crossdisciplinary research team exploring digital competence and digital responsibility in Norway. She is a member of the executive committee of the Nordic Comparative and International Education Society (NOCIES) and is a co-editor of the Nordic Journal of Digital Literacy.

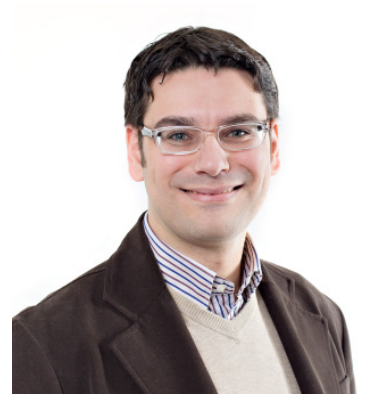

Massimo Loi is a researcher at the Norwegian Center for ICT in Education. He holds a Ph.D in Economics and Management from the University of Padua, Italy. His research interests cover the evaluation of public policies, the analysis of the effects of ICT in education and test development. At present he is part of the research team exploring digital competence and digital responsibility by school children, teachers and school leaders. 